\title{
Farmers dig into soil quality
}

Analytical technique promises to match fertilizers to soil in bid to boost yields in Africa.

\section{BY QUIRIN SCHIERMEIER}

$\mathrm{E}$ fforts to bring chemical fertilizers to subSaharan Africa are often met with concerns over harmful environmental and economic side effects. The products improve soil quality - useful in Africa, where soils often lack crucial nutrients - and help to increase yields. But fertilizers are costly for subsistence farmers and can leach into water supplies, leading to health problems. Soil scientists have long wanted to assist poor farmers with their selection and use of fertilizers so that they can better match them with soil types and use less of them.

At the Global Soil Week event in Berlin this week, researchers are presenting analytical tools that could enable them to do just that. Rapid soil-fertility assessment, a new spectroscopy technique used to analyse samples and produce site-specific soil maps for farmers, might help to halve the amount of fertilizer needed to bring food self-sufficiency to sub-Saharan Africa, according to proponents. Critics, however, argue that the technique is impractical and costly, and that organic fertilizers such as manure are cheaper and greener.

Malnourishment affects roughly $223 \mathrm{mil}-$ lion people in sub-Saharan Africa - about one-quarter of the region's total population according to estimates by the Food and Agriculture Organization (FAO) of the United Nations. Most of the region missed out on the 'green revolution' that occurred in the late 1940s to the 1960 s, which boosted crop yields in other parts of the world. Farmers in some areas of Africa have begun to adopt fertilizers only in the past decade. And, on average, they use just 9 kilograms per hectare each year, compared with more than 200 kilograms used in high-intensity agriculture, such as in Germany. Yields are typically $30-80 \%$ lower as a result.

Widespread use of chemical fertilizer has greatly increased food sufficiency in many countries, for example in China and India, but the ecological and health effects of fertilizer chemicals raise serious concerns. China, in particular, is facing a major pollution problem from overuse of nitrogen fertilizer, which can harm air quality and contaminate groundwater, suffocating aquatic life.

To avoid similar problems on African farms, scientists working with local farmers are exploring crop modelling and nutrient management. Field trials to assess the ecological efficiency of organic and chemical fertilizers in different geographic and climatic settings are under way in Ethiopia, Kenya, Malawi, Uganda and Tanzania.

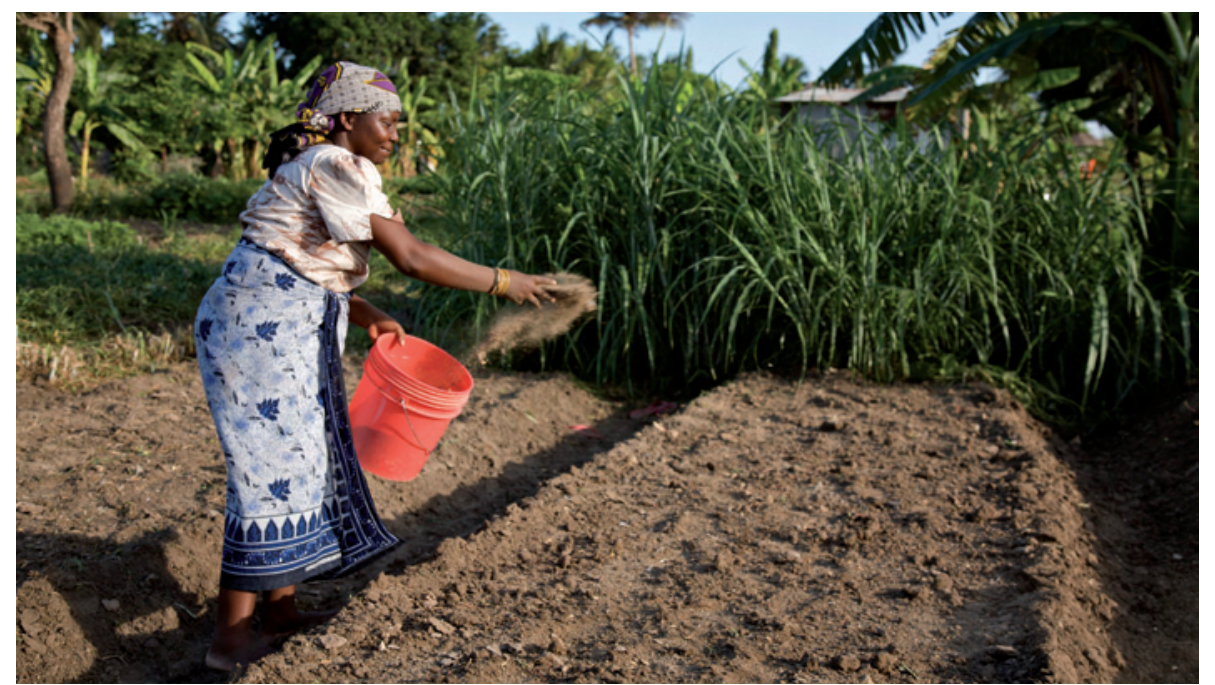

Farmers in sub-Saharan Africa must often contend with soils that lack nutrients for crop production.

The goal, says Rolf Sommer, an agricultural scientist at the International Center for Tropical Agriculture (CIAT) in Nairobi, is to provide smallholders with easy-to-understand information that will help them to decide what works best, economically and ecologically. To help, researchers at CIAT developed the spectroscopy technique, which uses mid-infrared light, to precisely determine the mineral properties, nutrient content and organic chemistry of subSaharan soils. Although still in its infancy, the technology could one day be used to evaluate and map the yield potential of soils across the region - information that would then be relayed to farmers. "If farmers know what fertilizer to use and when to use it, they'll need less and it will work better," says Sommer.

Agronomists, he adds, would also be able to make informed recommendations on the right mix and most economical use of fertilizers - a practice that would help to avoid the ecological and monetary costs of fertilizer overuse.

"We do need to increase food productivity in a sustainable way," says Ronald Vargas, a soils and land management officer at the FAO in Rome. "Understanding the health and condition of tropical soils is a prerequisite for any wise use of fertilizers." Advances in soil spectroscopy are "very promising", he adds, and spectral analysis is on the agenda of a special FAO workshop on soil monitoring in Rome this December.

Others are unconvinced. Although soil analysis is "very important", says Johannes Kotschi, a soil scientist at the Association for Agriculture and Ecology in Marburg, Germany, "the notion that intricate and expensive lab technology will influence farming practices in sub-Saharan Africa is far-fetched". Soil nutrients and soil acidity can be easily determined with readily available, cheap test strips, he adds.

Kotschi also thinks that organic fertilizers such as manure, compost and plant residues should play a greater part in efforts to increase productivity. "Nitrogen fertilizer isn't a quick fix to soil problems," he says. "Its use produces greenhouse gases and it ruins soil fertility rather than improving it." He points out that many smallholders in sub-Saharan Africa can scarcely afford to buy mineral fertilizers anyway.

Most agricultural scientists acknowledge that applying only chemical fertilizers is not the solution to Africa's yield problem. But an organiconly solution, favoured by environmental groups such as Greenpeace, will also fall short, says Sommer.

"Conservation agriculture is excessively timeconsuming, and organic fertilizer produced onfarm does not replenish soils with nutrients," he says. "We will need to find solutions that fit local farmers. The times when African farmers blindly applied what Western scientists thought was good for them are definitely over." -

\section{CORRECTION}

The News story 'Final word is near on darkmatter signal' (Nature 502, 421; 2013), wrongly quoted Jonathan Feng as saying the LUX results could rule out all types of neutralino - he believes that only some types would be ruled out. 